\title{
Effects of HSPA8, an evolutionarily conserved oviductal protein, on boar and bull spermatozoa
}

\author{
Roslyn M A Elliott ${ }^{1}$, Rhiannon E Lloyd ${ }^{1}$, Alireza Fazeli ${ }^{2}$, Edita Sostaric ${ }^{2}$, A Stephen Georgiou ${ }^{2}$, \\ Nana Satake ${ }^{1,3}$, Paul F Watson ${ }^{3}$ and William V Holt ${ }^{1}$ \\ ${ }^{1}$ Institute of Zoology, Regent's Park, London NW1 4RY, UK, ${ }^{2}$ Academic Unit of Reproductive and Developmental \\ Medicine, The University of Sheffield, Level 4, The Jessop Wing, Tree Root Walk, Sheffield S10 2SF, UK and ${ }^{3}$ The Royal \\ Veterinary College, Royal College Street, London NW1 OTU, UK
}

Correspondence should be addressed to WV Holt; Email: bill.holt@ioz.ac.uk

\begin{abstract}
Previous studies have shown that a soluble protein fraction derived from preparations of apical plasma membrane (APM) of the oviductal epithelium enhances the in vitro survival of mammalian spermatozoa. Here, we show that the survival enhancing property of the soluble protein fraction seems to depend significantly upon heat shock 70 kDa protein 8 (HSPA8 previously known as HSPA10). The following findings in the present study enabled us to draw this conclusion: first, using proteomic analysis, we identified a subset of $70 \mathrm{kDa}$ oviductal surface proteins that bound to spermatozoa, one of which was HSPA8. Second, pre-treatment of the soluble protein fraction with antiHSPA8 antibody reduced the $24 \mathrm{~h}\left(\right.$ at $39{ }^{\circ} \mathrm{C}$ ) sperm survival enhancement effect normally induced by the presence of $200 \mu \mathrm{g} / \mathrm{ml} \mathrm{soluble}$ APM proteins. Third, complementary experiments showed that substituting the soluble protein fraction with bovine recombinant $\mathrm{HSPA} 8$ $(0.5-2 \mu \mathrm{g} / \mathrm{ml})$ also elicited the sperm survival effect. Finally, we also tested the effect of bovine recombinant HSPA8 on bull spermatozoa and found similar, dose-responsive, sperm survival promoting effects. The conserved nature of HSPA8 between mammalian species suggests that this protein may represent a common biological mechanism for the maintenance of sperm survival in the oviduct.

Reproduction (2009) 137 191-203
\end{abstract}

\section{Introduction}

Sperm storage in the female reproductive tract has been extensively documented in a range of vertebrates that includes sharks (Pratt \& Tanaka 1994), salamanders (Sever \& Brizzi 1998), snakes and turtles (Galbraith 1993, Gist \& Congdon 1998) as well as many birds and mammals. Some of these species, especially the snakes and turtles, store spermatozoa for several months, or even years, prior to fertilization. In general, mammals are only able to store spermatozoa for a few days in the female reproductive tract (Rodriguez-Martinez et al. 2005, Holt et al. 2006, Rodriguez-Martinez 2007), although some bat species have evolved successful means of storing spermatozoa for several months over winter in the uterus or oviduct (Racey \& Potts 1970, Racey 1979, Racey et al. 1987, Holt et al. 2006). The mechanisms involved in prolonging sperm survival in the female reproductive tract have remained largely elusive, although the widely observed (Hunter 1981, Pacey et al. 1995, Hunter \& Rodriguez-Martinez 2004) formation of intimate associations between spermatozoa and the oviductal epithelial surface suggests that membrane-membrane contact is likely to be important.
Such inter-membrane contact is likely to stimulate mutual cell signalling dialogues between the spermatozoa and oviductal cells, with resultant effects on the activity of both cell types. Oviductal epithelial cells (OEC) are now known to respond by modulating gene transcription and protein synthesis (Georgiou et al. 2005) while (boar) spermatozoa respond to the presence of oviductal proteins with reduced motility and an accelerated increase in intracellular $\mathrm{pH}$ (Satake et al. 2006).

Co-culture of spermatozoa with OEC has repeatedly been shown to prolong sperm viability in some species, including pigs. In this laboratory, we have consistently demonstrated the enhancement of boar sperm viability by a soluble fraction of oviductal apical plasma membrane (sAPM) proteins (Elliott et al. 2001, Fazeli et al. 2003, Holt et al. 2005), derived from APM vesicles, as originally described by Smith \& Nothnick (1997). In bioassays involving incubation of boar spermatozoa with sAPM for $24 \mathrm{~h}$ at $39{ }^{\circ} \mathrm{C}$, sperm viability was enhanced in a dose-dependent manner (Fazeli et al. 2003). Moreover, the enhancement effect was abolished if sAPM proteins had been denatured (Fazeli et al. 2003). 
These results confirmed that one or more proteins within the SAPM contribute to the enhancement of sperm viability.

However, sAPM represents a complex mixture of proteins, any of which might be active at low concentration. This might explain why a relatively high concentration of SAPM $(200 \mu \mathrm{g} / \mathrm{ml})$ is necessary in order to demonstrate the viability enhancing effect. In a previous publication (Holt et al. 2005), we described in detail the preparation method for SAPM and demonstrated that we could distinguish oviduct epithelium surface-exposed proteins by the use of an in situ biotinylation technique. In the current study, we have again used in situ biotinylated oviductal sAPM preparation and have tracked the binding of this protein preparation to the surface of co-incubated spermatozoa. We have also studied the sperm binding topology in some detail using confocal microscopy and used proteomic analyses to identify heat shock $70 \mathrm{kDa}$ protein 8 (HSPA8 previously known as HSPA10, HSC71, HSC70 and HSP73) as a probable significant functional component of the sAPM. Ultimately, using bovine recombinant HSPA8 protein, we replicated the spermsurvival enhancement effect of sAPM, not only in boar spermatozoa but also in bull spermatozoa.

\section{Results}

\section{Association of sAPM proteins with spermatozoa}

Two different approaches were used to examine the association of surface oviductal SAPM proteins and spermatozoa. In the first experiment, in situ biotinylated sAPM proteins were bound to Immobilized NeutrAvidin coated beads, which were then co-incubated with spermatozoa to see whether any physical binding occurred. The control sample consisted of NeutrAvidincoated beads with no surface-bound sAPM. The second experiment involved visualization of SAPM proteins by confocal microscopy. Aliquots of sAPM were directly labelled with FITC to provide visible evidence of proteins associating with spermatozoa.

Examination of live images of the sperm-bead interactions revealed that unexpectedly small numbers of spermatozoa became bound to the bead surfaces. Even those that became bound tended to be released again after a few seconds. This lack of firm binding was not caused by any shortage of spermatozoa in the surrounding media and may therefore indicate that some degree of sperm selection was involved. Visual estimates nevertheless showed that the number of spermatozoa associated with SAPM-treated beads (regardless of whether the SAPM had been biotinylated ex-situ or in-situ) was about fivefold greater than became bound to untreated beads (five sperm/bead for ex-situ labelled SAPM; 4.4 sperm/bead for in situ labelled SAPM; control values were 0.75 and 0.82 sperm/bead respectively: $P=0.02$ ). As it was not possible to examine the whole of the bead surface by video microscopy, some sperm-bead preparations (made using live spermatozoa labelled with SYBR14) were fixed and examined by confocal microscopy to check the uniformity and low level of binding. Slices through an SAPM-treated bead and a control bead are shown in Fig. $1 \mathrm{~A}$ and $\mathrm{B}$ respectively. The confocal microscopy confirmed that relatively few spermatozoa were bound to the bead surfaces.

Fluorescence microscopy of spermatozoa incubated with FITC-labelled SAPM showed that binding mostly occurred on the apical segment of the acrosome in plasma-membrane intact propidium lodide $(\mathrm{PI}-\mathrm{ve})$ spermatozoa (mean \pm s.E.M.: $63.1 \pm 6.1 \% ; n=8$ boars), although some spermatozoa exhibited more extensive binding over the whole of the sperm head or over the

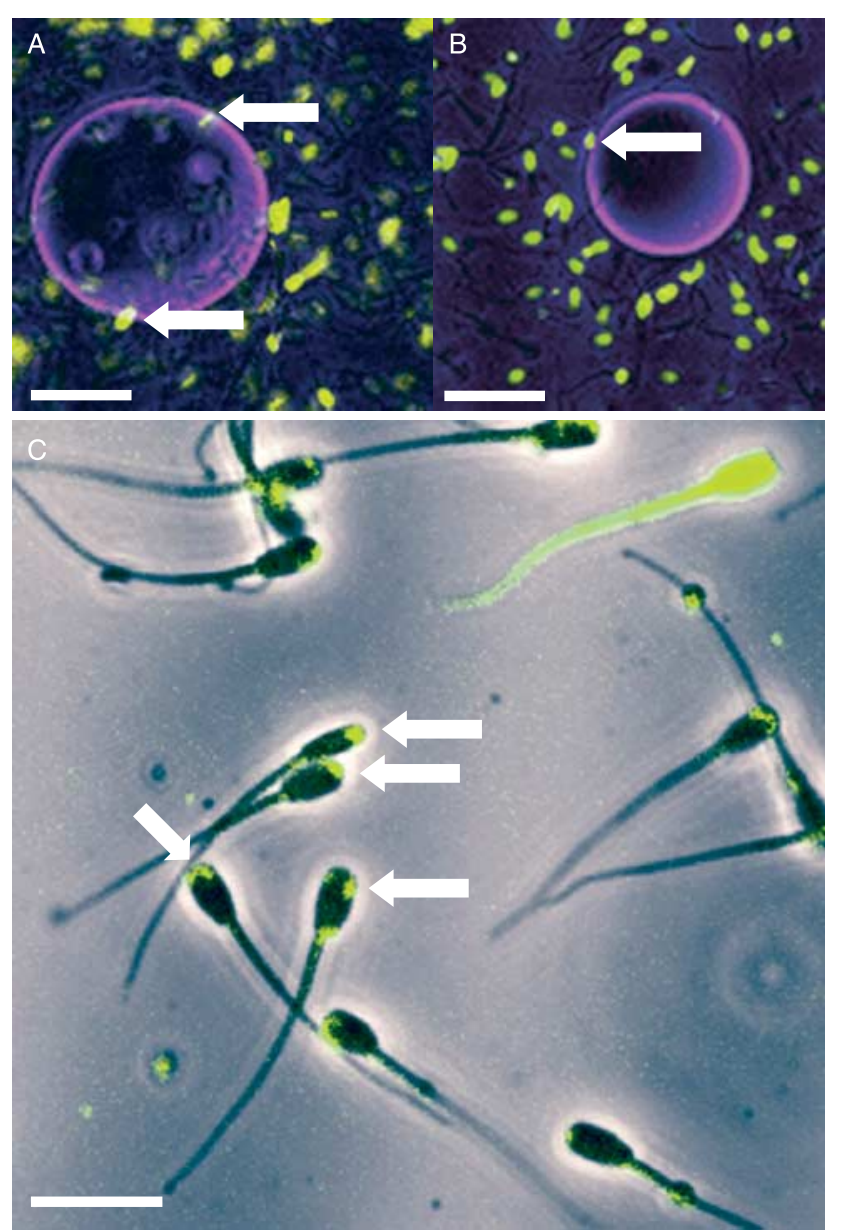

Figure 1 Confocal images through a single sAPM-coated bead (A) incubated with SYBR-14 labelled spermatozoa and a control, untreated, bead (B); relatively few spermatozoa were bound to the bead (see white arrows). Scale bars $=100 \mu \mathrm{m}$. (C) shows that many sperm heads bind FITC- labelled SAPM at the apical region of the acrosome (white arrows), while a few spermatozoa bind sAPM over their entire head, middle-piece and tail. Scale bar $=20 \mu \mathrm{m}$. 
head and whole or part of the flagellum (mean \pm s.E.M.: $18.3 \pm 3.24 \%: n=8$ boars). Approximately $18 \%$ spermatozoa (mean \pm s.E.M.; $18.6 \pm 5.1 \% ; n=8$ boars) did not appear to bind any of the labelled sAPM at all. Examples are presented in Fig. 1C.

\section{Identification of in situ biotinylated oviductal epithelial proteins that bind to spermatozoa}

Immunoblotting of the combined solubilized sperm membrane protein fraction with sperm surface-bound biotin-labelled SAPM demonstrated specific binding of a protein fraction of $\sim 70 \mathrm{kDa}$. In order to identify this protein(s), the corresponding protein band from a series of replicate SDS-PAGE gels was excised for proteomic analysis.

Figure 2A presents a PAGE gel showing that while many proteins were contained within the in situ biotinylated SAPM fraction, after incubation of the
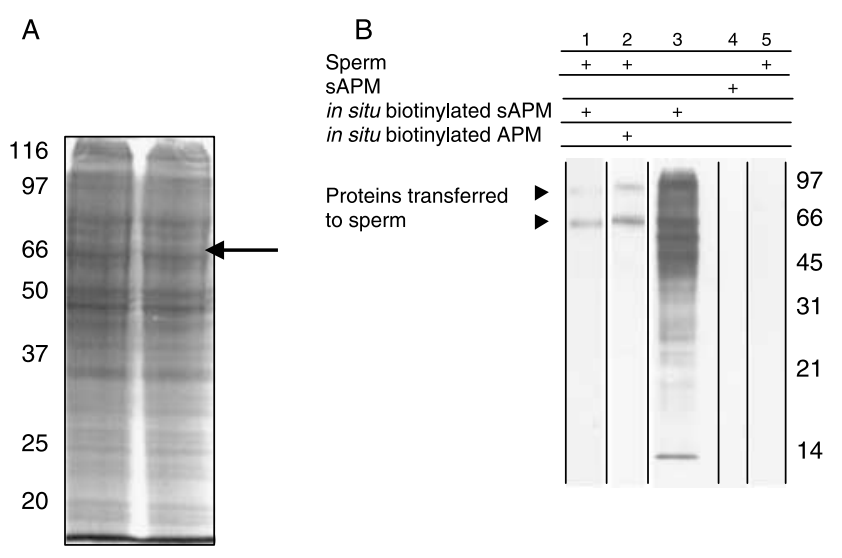

C

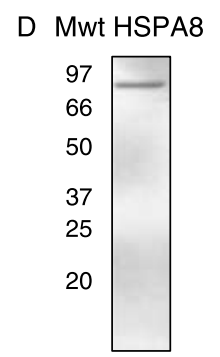

Figure 2 (A) One-dimensional protein profile of sAPM (both lanes); the protein band at $70 \mathrm{kDa}$ (arrow) corresponds to the positively stained band at $70 \mathrm{kDa}$ in the blot illustrated in (B) (Lane 1); this band was excised from a series of gels and subjected to proteomic analysis. The blot (B) (lane 1) indicates that the $70 \mathrm{kDa}$ sAPM protein was transferred to spermatozoa during sperm-sAPM incubation. A second band of $\sim 90 \mathrm{kDa}(\mathrm{B})$, lane 1; arrow) was also transferred to spermatozoa, but was not investigated further. Figure B (Lane 2) shows that the same two subsets of APM proteins were also transferred to spermatozoa during incubation. Lane 3 shows the biotinylation profile of in situ biotinylated sAPM; Lanes 4 and 5 show the absence of the biotinylation signal in unlabelled sAPM proteins and spermatozoa respectively. (c). PAGE protein profile of sAPM (both lanes). (D) A western blot of SAPM probed with an antibody against HSPA8.
sAPM with spermatozoa only one band ( $\mathrm{MWt}$ $\sim 70 \mathrm{kDa}$ ) was strongly detectable on the blot (Fig. 2B, Lane 1). Lane 2 in this figure shows that when spermatozoa were incubated with APM (i.e. nonsolubilized biotinylated APM), they bound not only this protein band, but also another with a molecular weight of about $97 \mathrm{kDa}$ (Fig. 2B, lane 2).

To identify the proteins contained within the spermbinding $70 \mathrm{kDa}$ band, the relevant band was excised (Fig. 2C) from 16 lanes of two gels prepared in parallel and their protein composition analyzed in detail. The proteomic analysis identified 19 proteins (listed in Table 1) within this band. It was not feasible to investigate all the 19 proteins in detail, therefore, as a first step we chose to investigate one of these proteins, namely HSPA8, in more detail. Western blotting showed a strong immunoreactivity between SAPM and anti-HSPA8, confirming the presence of HSPA8 in SAPM.

\section{Neutralization of SAPM with anti-HSPAB}

In view of the ability of proteins within the SAPM to interact with spermatozoa, the next step was to see whether the ability of sAPM to enhance sperm viability would be compromised by adsorption with anti-HSPA8. A preliminary experiment showed that anti-HSPA8 diluted to $1 \mu \mathrm{g} / \mathrm{ml}$ largely prevented the binding of FITC-labelled SAPM to spermatozoa. This dilution factor was therefore used in tests aimed at blocking the SAPM effects on sperm viability. When the $24 \mathrm{~h}$ bioassays were repeated using SAPM and SAPM treated with antiHSPA8, it was found that sperm survival was significantly higher in the former compared with the latter $(P=0.013$; Fig. 3A).

\section{Effects of HSPA8 on boar spermatozoa incubated for $24 \mathrm{~h}$ at $39^{\circ} \mathrm{C}$}

To test the effects of HSPA8 itself on boar sperm survival at $39^{\circ} \mathrm{C}$ under capacitating conditions, washed spermatozoa were incubated in Tyrode's medium with lactate and pyruvate (TLP) containing $0,2,4,8$ and $16 \mu \mathrm{g} / \mathrm{ml}$ HSPA8 for $24 \mathrm{~h}$ and then evaluated for its viability. There was a significant overall enhancement of sperm survival, represented by a $15 \%$ increase in viability index, due to the presence of HSPA8 $(P=0.007)$. However, this beneficial effect appeared to be optimal at $2 \mu \mathrm{g} / \mathrm{ml}$ $\left(P=0.0007 ; \quad F_{1 / 24}=14.9\right)$ and there was no further benefit to be gained by further increasing the concentration of protein.

This outcome was pursued further by repeating the bioassays, but using lower concentrations of HSPA8 (0, $0.25,0.5,2$ and $8 \mu \mathrm{g} / \mathrm{ml}$ ). As an additional comparison, the spermatozoa were also incubated in the presence of $200 \mu \mathrm{g} / \mathrm{ml} \mathrm{sAPM}$ to evaluate the effectiveness of HSPA8 against the original oviductal preparation. The beneficial 
Table 1 Protein components of the sperm-binding $70 \mathrm{kDa}$ sAPM band.

\begin{tabular}{|c|c|c|c|c|c|c|c|c|}
\hline $\begin{array}{l}\text { Protein } \\
\text { number }\end{array}$ & Protein name & $\begin{array}{c}\text { Previous name; aliases. } \\
\text { Protein family }\end{array}$ & $\begin{array}{c}\text { Accession } \\
\text { number (Uniprot) }\end{array}$ & $\begin{array}{l}\text { MOWSE score } \\
\text { (MASCOT) }\end{array}$ & $\begin{array}{c}\text { Theoretical } \\
\text { protein } \mathrm{MW}(\mathrm{kDa})\end{array}$ & $\begin{array}{l}\text { Peptides } \\
\text { identified }\end{array}$ & $\begin{array}{l}\text { Sample peptide } \\
\text { sequence(s) }\end{array}$ & $\begin{array}{l}\text { Sample peptide } \\
\text { e-value(s) }\end{array}$ \\
\hline 1 & $\begin{array}{l}\text { Heat shock protein } \\
90 \text { kDa beta } \\
\text { (Grp94), member } 1 \\
\text { (HSP90B1) }\end{array}$ & $\begin{array}{l}\text { TRA1; GP96 and } \\
\text { GRP94. HSP90 } \\
\text { protein family }\end{array}$ & A53211 & 445 & 92456 & 11 & $\begin{array}{l}\text { K.LIINSLYK.N, } \\
\text { K.IYFMAGSSR.K }\end{array}$ & $1.4,1.5$ \\
\hline 2 & $\begin{array}{l}\text { Heat shock protein } \\
90 \mathrm{kDa} \alpha \text { (cytosolic), } \\
\text { class A member } 1 \\
\text { (HSP90AA1) }\end{array}$ & $\begin{array}{l}\text { HSPC1, HSPCA; } \\
\text { HSP89, HSP90, } \\
\text { FLJ31884, } \\
\text { HSP90N. HSP90 } \\
\text { protein family }\end{array}$ & Q2VPJ6_HUMAN & 74 & 68329 & 3 & $\begin{array}{l}\text { R.APFDLFENR.K, } \\
\text { R.GVVDSEDLPLNISR.E }\end{array}$ & $5.3,0.13$ \\
\hline 3 & $\begin{array}{l}\text { Heat shock protein } \\
90 \mathrm{kDa} \alpha \text { (cytosolic), } \\
\text { class B member } 1 \\
\text { (HSP90AB1) }\end{array}$ & $\begin{array}{l}\text { HSPC2, HSPCB. } \\
\text { HSP90 protein } \\
\text { family }\end{array}$ & Q1PSW2_RAT & 114 & 83230 & 3 & $\begin{array}{l}\text { R.ELISNASDALDK.I, } \\
\text { R.GVVDSEDLPLNISR.E }\end{array}$ & $0.00062,0.13$ \\
\hline 4 & $\begin{array}{l}\text { Heat shock } 70 \mathrm{kDa} \\
\text { protein } 5 \text { (glucose- } \\
\text { regulated protein, } \\
78 \mathrm{kDa} \text { (HSPA5) }\end{array}$ & $\begin{array}{l}\text { GRP78; BIP. HSPA4 } \\
\text { protein family }\end{array}$ & HHRTGB & 357 & 72302 & 9 & $\begin{array}{l}\text { K.ITITNDQNR.L, } \\
\text { R.NELESYAYSLK.N }\end{array}$ & $2.7,0.075$ \\
\hline 5 & $\begin{array}{l}\text { Heat shock } 70 \mathrm{kDa} \\
\text { protein } 8 \text { (HSPA8) }\end{array}$ & $\begin{array}{l}\text { HSPA10; HSC71, } \\
\text { HSC70, HSP73. } \\
\text { HSP70 protein } \\
\text { family }\end{array}$ & $1 \mathrm{NGB}$ & 54 & 71241 & 1 & R.IINQPTAAAIAYGLDK.K & 0.0063 \\
\hline 6 & Clusterin (CLU) & $\begin{array}{l}\text { CLI, APOJ; SGP-2, } \\
\text { SP-40, TRPM_2, } \\
\text { KUB1. CLU protein } \\
\text { family }\end{array}$ & A42108 & 155 & 51741 & 6 & $\begin{array}{l}\text { K.SLLSSLEEAK.K, } \\
\text { R.ASNIMDELFQDR.F }\end{array}$ & $0.28,31$ \\
\hline 7 & $\begin{array}{l}\text { Activated leukocyte } \\
\text { cell adhesion } \\
\text { molecule (ALCAM) }\end{array}$ & CD166, MEMD & Q1HGM8_HUMAN & 114 & 65061 & 2 & $\begin{array}{l}\text { R.SSNTYTLTDVR.R, } \\
\text { K.SVQYDDVPEYK.D }\end{array}$ & $0.00035,0.032$ \\
\hline 8 & $\begin{array}{l}\text { Sec23 homolog B } \\
\text { (S. cerevisiae) } \\
\text { (SEC23B) }\end{array}$ & & SEC23B & 50 & 86407 & 2 & K.IDMNLTDLLGELQR.D & 0.16 \\
\hline 9 & Gelsolin (GSN) & $\begin{array}{l}\text { Gelsolin protein } \\
\text { family }\end{array}$ & FAHUP & 145 & 85644 & 3 & $\begin{array}{l}\text { K.TGAQELLR.V, } \\
\text { K.AGALNSNDAFVLK.T }\end{array}$ & $1.8,0.035$ \\
\hline \multirow[t]{2}{*}{10} & $\begin{array}{l}\text { Oviductal } \\
\text { glycoprotein 1, } \\
120 \mathrm{kDa} \text { (mucin 9, } \\
\text { oviductin) (OVGP1) }\end{array}$ & $\begin{array}{l}\text { MUC9; CHIT5. } \\
\text { Glycosyl hydrolase } \\
18 \text { family }\end{array}$ & AAA85445 & 280 & 58482 & 7 & $\begin{array}{l}\text { K.LLMGFPTYGR.T, } \\
\text { K.SSAYTMNYWR.K }\end{array}$ & $2.6,0.043$ \\
\hline & & & Q8C6P2_MOUSE & 93 & 34989 & 2 & $\begin{array}{l}\text { K.LIMGFPTYGR.N, } \\
\text { K.TLLSIGGWNFGTSR.F }\end{array}$ & $2.6,0.00038$ \\
\hline \multirow[t]{2}{*}{11} & Ezrin (EZR) & $\begin{array}{l}\text { VIL2. Ezrin-radixin- } \\
\text { moesin protein } \\
\text { family }\end{array}$ & EZRI_BOVIN & 335 & 68586 & 9 & $\begin{array}{l}\text { K.IALLEEAR.R, } \\
\text { R.ALKLEEER.K }\end{array}$ & $1.6,0.01$ \\
\hline & & & EZRI_MOUSE & 261 & 69233 & 8 & $\begin{array}{l}\text { K.IALLEEAR.R, } \\
\text { K.ALQLEEER.R }\end{array}$ & $1.6,0.01$ \\
\hline \multirow[t]{2}{*}{12} & $\begin{array}{l}\text { Tropomyosin } 1 \\
\text { (TPM1) }\end{array}$ & $\begin{array}{l}\text { Tropomyosin } \\
\text { protein family }\end{array}$ & TMRTF1 & 78 & 32938 & 2 & $\begin{array}{l}\text { R.IQLVEEELDR.A, } \\
\text { K.TIDDLEETLASAK.E }\end{array}$ & $0.016,2.8$ \\
\hline & & & Q59GR8_HUMAN & 70 & 34382 & 2 & R.IQLVEEELDR.A & 0.016 \\
\hline 13 & $\begin{array}{l}\text { Tropomyosin } 3 \\
\text { (TPM3) }\end{array}$ & $\begin{array}{l}\text { Tropomyosin } \\
\text { protein family }\end{array}$ & Q5VU71_HUMAN & 118 & 32799 & 3 & R.IQLVEEELDR.A & 0.016 \\
\hline
\end{tabular}




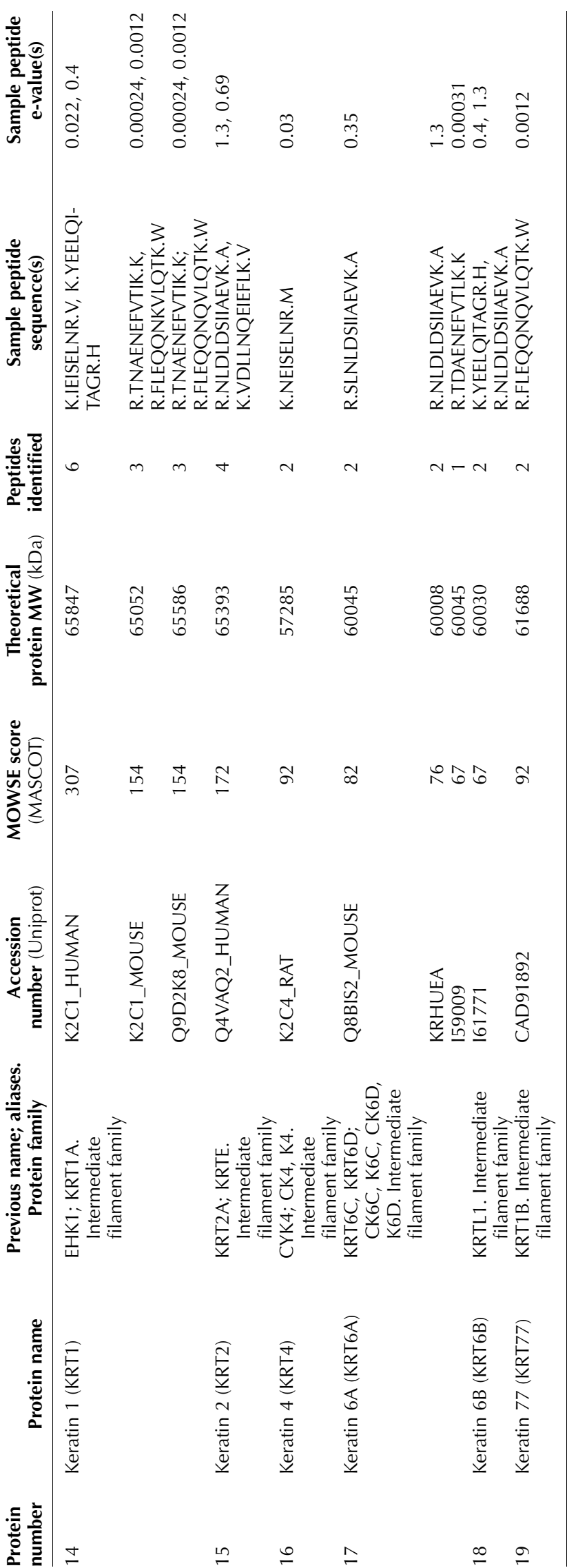

effects of HSPA8 were again evident at $2 \mu \mathrm{g} / \mathrm{ml}$ $\left(P=0.0037 ; F_{1 / 84}=8.89\right)$, as in the earlier experiment but to a lesser extent than both 0.25 and $0.5 \mu \mathrm{g} / \mathrm{ml}$ $(P=0.001)$ for the comparison between TLP and $0.25 \mu \mathrm{g} / \mathrm{ml}$ and $P<0.0001$ for the specific comparison between TLP and both concentrations together). $8 \mu \mathrm{g} / \mathrm{ml}$ had no beneficial effect on maintaining sperm survival and it was concluded that the optimal concentration must be lower than $2 \mu \mathrm{g} / \mathrm{ml}$ (Fig. 3B).

A further series of bioassays was therefore undertaken using an even lower range of HSPA8 concentrations $(0.1,0.5$ and $4 \mu \mathrm{g} / \mathrm{ml})$; and sAPM $(200 \mu \mathrm{g} / \mathrm{ml})$ treatment was also included (Fig. 3C). Beneficial effects on sperm survival over a $24 \mathrm{~h}$ period were evident with HSPA8 at $0.1 \mu \mathrm{g} / \mathrm{ml}(P=0.005)$ and $0.5 \mu \mathrm{g} / \mathrm{ml}(P=0.0001)$. In this experiment, there was no beneficial effect observed with HSPA8 at $4 \mu \mathrm{g} / \mathrm{ml}$. As $0.5 \mu \mathrm{g} / \mathrm{ml}$ HSPA8 had the greatest beneficial effect on sperm viability (Fig. $3 \mathrm{~A}$ and $\mathrm{C})$, it was concluded that this must be the optimal concentration of HSPA8.

\section{In vitro fertilization assays}

Spermatozoa were briefly ( $10 \mathrm{~min}$ ) exposed to $0.5 \mu \mathrm{g} / \mathrm{ml}$ recombinant bovine HSPA8 protein before being diluted (1: 200) into the final fertilization droplet. A control treatment with no protein exposure was also set up. The summarised IVF results are shown in Table 2. Exposure to HSPA8 did not enhance the fertilization rate compared with the control, but it significantly enhanced the extent of monospermy (control versus HSPA8; 58.6 vs $88.9 \%$; $P<0.05)$. Exposing spermatozoa to HSPA8 also appeared to increase the rate of embryonic development so that by $60 \mathrm{~h}$ of incubation a markedly higher proportion of embryos had reached or passed the three or four cell stage (control versus HSPA8; 37.9 vs $74.1 \%$ and 3.5 and $22.2 \%$ respectively; $P<0.05$ ).

\section{Effects of HSPA8 on bull spermatozoa incubated at $37^{\circ} \mathrm{C}$ for $48 \mathrm{~h}$}

As HSPA8 had a beneficial effect on boar sperm viability, despite being a bovine recombinant protein, we hypothesized that its role in sperm viability maintenance would also apply to the bull. To test this hypothesis, a sperm viability experiment was set up using bull, instead of boar, spermatozoa.

When bull spermatozoa were incubated in the presence of HSPA8 for $48 \mathrm{~h}$ at $37^{\circ} \mathrm{C}, \sim 50 \%$ remained viable. However, the inclusion of HSPA8 in the TLP medium increased the rate of sperm survival in a dose dependent manner up to an optimal value at $1 \mu \mathrm{g} / \mathrm{ml}$ (TLP control versus $1 \mu \mathrm{g} / \mathrm{ml}$ HSPA8; $P=0.0013$ ). Although, increasing the dose of HSPA8 further (to $4 \mu \mathrm{g} / \mathrm{ml}$ ) still resulted in a beneficial effect on sperm survival $(P=0.006)$ compared with TLPalone, the higher 

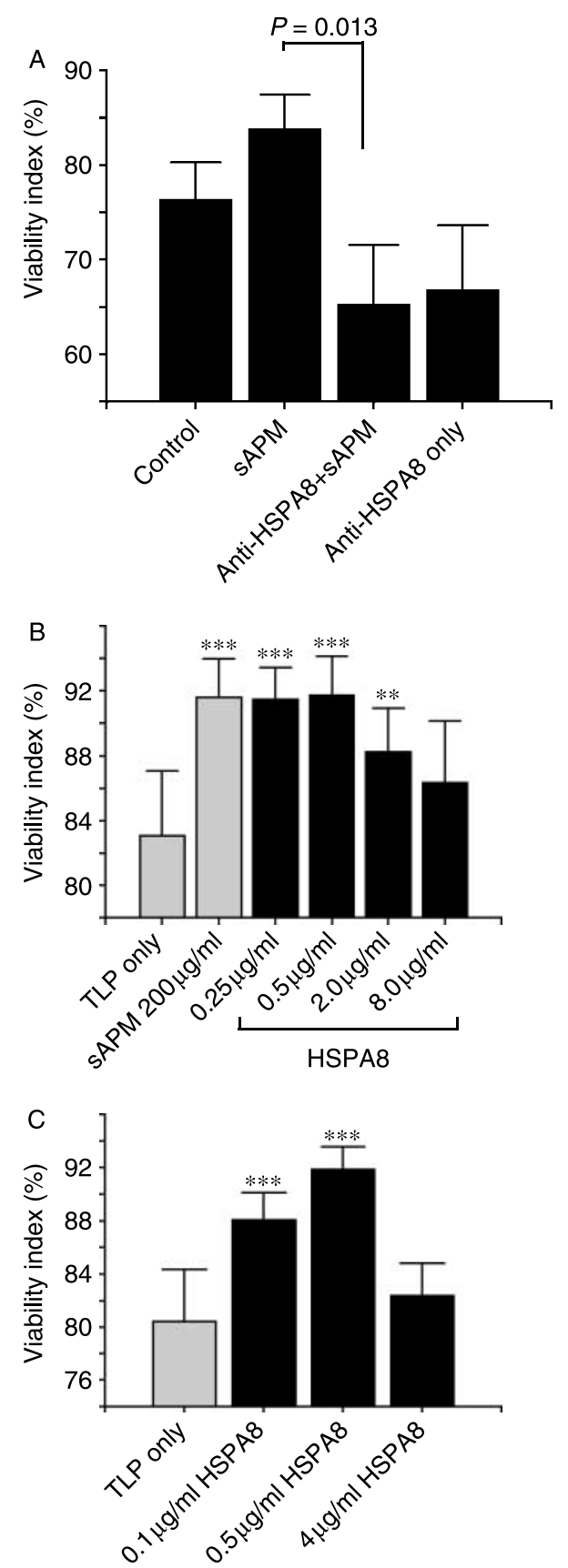

Figure 3 (A) Viability index (mean \pm S.E.M.) of boar spermatozoa incubated for $24 \mathrm{~h}$ at $39^{\circ} \mathrm{C}$ in the presence of TALP only (Control), $200 \mu \mathrm{g} / \mathrm{mlsAPM}$ (sAPM), sAPM treated with anti-HSPA8 (anti-HSPA8 + sAPM) and antiHSPA8 only. (B) and (C). Viability index (mean \pm S.E.M.) of boar spermatozoa incubated for $24 \mathrm{~h}$ at $39^{\circ} \mathrm{C}$ presence of TLP, SAPM $(200 \mu \mathrm{g} / \mathrm{ml})$ or two concentration ranges ((B) and (C) of bovine recombinant HSPA8. Significant beneficial effects of the protein treatments on sperm viability are indicated as follows: ${ }^{* *} P<0.001{ }^{* * *} P<0.0001$.

dose was less effective at maintaining sperm survival. When spermatozoa were incubated in media containing tubulin as a control protein treatment, there was no significant difference in outcome with respect to the TLP control. These results are summarised in Fig. 4.

\section{Discussion}

HSPA8 demonstrated consistent and significant enhancement of viability at low concentrations $(0.5-4 \mu \mathrm{g} / \mathrm{ml})$ for both porcine and bovine spermatozoa. As oviductal sperm storage is so widely observed in nature, it is likely that the fundamental physiological and biochemical mechanisms may also have been conserved across species. The present study is consistent with this view as it has revealed a role for the highly conserved protein HSPA8 in the sperm storage process; in fact, this molecule is sometimes regarded as the most highly conserved protein in nature (Daugaard et al. 2007).

In this study, we have demonstrated that the HSPA8 is present within a soluble protein subset prepared from the porcine oviductal epithelium, sAPM, and that recombinant bovine HSPA8 enhances the in vitro survival of both boar and bull spermatozoa. Thus, we conclude that the HSPA8 is likely to be a biologically active sAPM component responsible for improved in vitro sperm survival that we have observed and reported previously (Elliott et al. 2001). Our investigative strategy involved two complementary approaches; one was the direct proteomic identification of biotinylated SAPM proteins that became bound to the sperm surface. This approach was informative because the SAPM had been prepared from in situ biotinylated OEC; therefore the biotinlabelled proteins must have originated on or near the oviductal cell surface. The second approach aimed to use the proteomic information by incubating the SAPM with anti-HSPA8 in an effort to inactivate HSPA8, the selected protein of interest. The investigative strategy was then taken a step further by testing the biological activity of commercially available bovine recombinant HSPA8 in sperm survival bioassays. This protein was shown to be capable of reproducing the sperm-enhancing properties of sAPM, but at considerably lower concentrations.

As a prelude to these studies we also showed, by confocal microscopy, that when spermatozoa and fluorescent-labelled sAPM proteins are co-incubated, the sAPM proteins bind predominantly to the apical region of the sperm head. This together with evidence of boar sperm binding to SAPM coated beads supports the findings of our earlier work whereby a small number of surface labelled sAPM proteins were found to associate with spermatozoa during incubation (Satake et al. 2006). The majority of boar spermatozoa (63.1\%) bound FITC-labelled sAPM proteins at the apical region of the sperm head; this is the region that associates with OEC in vivo (Rodriguez-Martinez 2007) and suggests that the sAPM-sperm interaction mimics the natural situation. This also correlates with binding patterns and interactions seen in other studies (Pollard et al. 1991, Pacey et al. 1995, Satake et al. 2006). Binding over the anterior acrosome also coincides with the distribution of sulphated glycolipids reported by Gadella et al. (1995); interestingly, the sulphated glycolipids are known to bind specifically to members of the HSP70 family, especially 
Table 2 Effect of exposing spermatozoa to HSPA8 protein for $10 \mathrm{~min}$ prior to transfer into the IVF droplet.

\begin{tabular}{|c|c|c|c|c|c|c|c|c|}
\hline Treatment & $\begin{array}{l}\text { Number of } \\
\text { oocytes }\end{array}$ & $\begin{array}{l}\text { Degenerate } \\
\text { oocytes }\end{array}$ & $\begin{array}{l}\text { Failed to } \\
\text { fertilize }\end{array}$ & $\begin{array}{c}\text { Fertilized } \\
(\%)\end{array}$ & $\begin{array}{c}\text { Monospermic } \\
(\%)\end{array}$ & $\begin{array}{c}\text { 2PN stage } \\
\text { or later } \\
\text { (\% of fertilized) }\end{array}$ & $\begin{array}{c}3 \text { or } 4 \text { cell } \\
\text { embryos } \\
\text { or later } \\
\text { (\% of fertilized })\end{array}$ & $\begin{array}{c}7 / 8 \text { cell } \\
\text { embryos or } \\
\text { later } \\
\text { (\% of fertilized) }\end{array}$ \\
\hline Control & 72 & 26 & 17 & $29(40.3)$ & 17 (58.6) & $16(55.1)$ & $11(37.9)$ & $1(3.5)$ \\
\hline HSPA8 & 72 & 35 & 10 & $27(37.5)$ & $24(88.9)^{*}$ & $27(100)$ & $20(74.1)^{*}$ & $6(22.2)^{*}$ \\
\hline Total & 144 & 61 & 27 & 56 & 41 & 43 & 31 & 7 \\
\hline
\end{tabular}

*Significantly higher than control values in the same column. $P<0.05$.

HSPA8, through specific binding sites on the protein molecule (Boulanger et al. 1995, Lingwood et al. 2001, Mamelak et al. 2001). If this binding interaction is indeed functionally significant, it would explain the dosedependent sperm-protein interaction observed here because the sperm surface-receptors would have to interact stoichiometrically with the exogenous protein. Since the anterior acrosomal sulphated glycolipid pattern reported by Gadella et al. (1995) undergoes a significant shift towards the equatorial segment during capacitation, we interpret our acrosomal patterns as indicating that most spermatozoa in our samples are uncapacitated; this would be expected as they had only been exposed to capacitation conditions for a very short period. This result would also agree with previous studies indicating that uncapacitated boar spermatozoa preferentially associate with OEC (Fazeli et al. 1999). That other spermatozoa either displayed extensive SAPM binding or no binding at all is therefore likely to be a reflection of sperm heterogeneity in the ejaculate; this is a well known property of boar ejaculates even though the specific reasons for the heterogeneity remain unclear. It is likely, however, that the differences correspond to inter-sperm differences in ability to colonise the oviduct.

Our attempt to mimic the sperm-oviduct interaction more precisely by incubating SAPM-coated beads with spermatozoa were of interest in that a surprisingly low number of spermatozoa became attached to each bead; although, this number was very low, it was nevertheless higher than the control beads that lacked surface-bound sAPM. There are a number of possible reasons for this, one plausible possibility being that the spermatozoa were only able to bind transiently to the bead surfaces, thus preventing the accumulation of spermatozoa. We did not, however, assess the effective density of sAPM bound to the bead surfaces, and a second possibility would be that the SAPM had been insufficiently coupled to the bead surface.

Further sperm/sAPM binding experiments enabled a subset of sperm-associating proteins to be identified using in situ biotinylated SAPM, followed by proteomic analysis of a significant $70 \mathrm{kDa}$ sperm-binding protein band. Of the 19 proteins identified from the significant $70 \mathrm{kDa}$ sperm-binding protein band, five were heat shock proteins and we chose to analyse one of these, namely
HSPA8, in more detail. A western blot of sAPM proteins probed with anti-HSPA8 confirmed its presence in SAPM.

sAPM was unable to enhance sperm viability if it had been pre-treated with anti-HSPA8. We interpreted this result as showing that HSPA8 could be a member of the sAPM protein milieu participating in the protection of sperm viability in vitro. Incubations (bioassays) of spermatozoa with serial dilutions of the commercial bovine recombinant HSPA8 confirmed this view by clearly demonstrating its effectiveness in enhancing sperm survival in vitro at concentrations that were $\sim$ two orders of magnitude lower than the correspondingly bioactive SAPM concentration. It is of considerable interest that when the effectiveness of HSPA8 was tested with bull spermatozoa, it was again was seen to enhance sperm survival at low concentrations and in a dosedependent manner.

In this study, the HSPA8 protein was detected in SAPM via the direct proteomic analysis of the sperm-binding protein band and by western blotting with an antibody (anti-HSPA8). To our knowledge, this is the first report suggesting membrane bound or extracellularly located HSPA8 may have a role in the protection of spermatozoa in the oviduct, but the associated literature is consistent with the evidence we present here. HSPA8 is a constitutive member of the heat shock protein 70 family

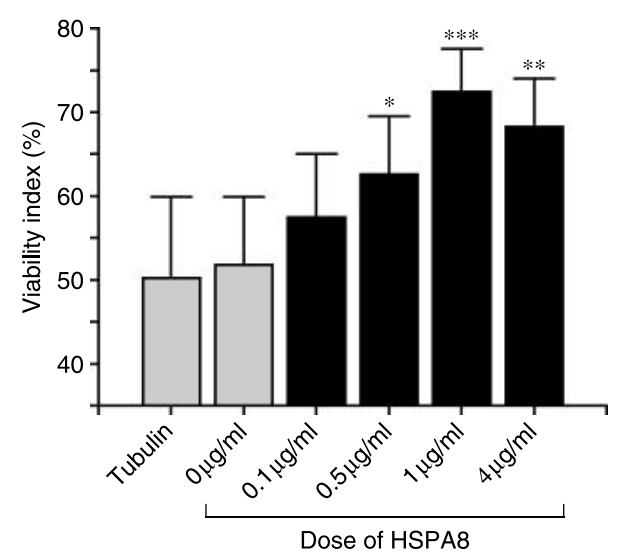

Figure 4 Viability index (mean \pm S.E.M.) of bull spermatozoa incubated for $48 \mathrm{~h}$ with various concentrations of bovine recombinant HSPA8. Significant beneficial effects of the protein treatments on sperm viability are indicated as follows: ${ }^{*} P<0.05^{* *} P<0.001^{* * *} P<0.0001$. 
that includes a number of HSP70 variants. Some are stress-inducible and others are constitutive with involvement in housekeeping functions (for reviews, see Tavaria et al. 1996, Daugaard et al. 2007). HSPA8 has been reported to be involved in a multitude of the housekeeping chaperone functions including folding of nascent polypeptides, protein translocation across membranes, chaperone-mediated autophagy, prevention of protein aggregation under stress conditions and disassembly of clathrin coated vesicles (Daugaard et al. 2007). Thus, HSPA8 is considered as an essential housekeeping gene and it has been reported that HSPA8 knockout-mice cannot be created due to the essential role of HSPA8 in cell survival.

When we undertook a parallel series of experiments using FITC-labelled HSPA8, we were unable to demonstrate the occurrence of any clear binding patterns to spermatozoa (data not shown). Logically, we conducted these experiments using HSP8A concentrations that matched the biologically significant range $(\sim 1-$ $4 \mu \mathrm{g} / \mathrm{ml}$ ). It could be argued that the concentration of FITC-labelled HSP8A protein was too low to be detectable on spermatozoa. However, it is also possible that HSP8A binds transiently to the functional sperm surface, exerting its effects instead by plasma membranemediated signalling mechanisms that probably operate via exceedingly low protein concentrations. This explanation would also be consistent with the large discrepancy between the concentration of SAPM and HSP8A needed to elicit improved sperm survival.

The reduction of polyspermic fertilization and improved rate of embryonic development in vitro by briefly exposing spermatozoa to HSPA8 before interaction with oocytes is of considerable interest but difficult to explain. The results agree with a previous and larger IVF study, using the same conditions, in which spermatozoa were exposed to SAPM for $10 \mathrm{~min}$ before fertilization (Satake et al. 2007). In that study, the overall fertilization rate was significantly enhanced from 78 to $86 \%$ ( $n=1235$ oocytes) when spermatozoa were preincubated with SAPM, and in the group of fertilized oocytes, polyspermic fertilization was also significantly reduced (47 vs $21 \%$ ). Given that HSPA8 is a component of SAPM, it may also have been one of the agents responsible for producing these earlier results. However, the possibility that the HSPA8 protein acts in concert with proteins that are either already present in the sperm plasma membrane or within the oviductal epithelium in vivo cannot be ruled out.

Like the study reported here, experiments by Boilard and colleagues (Boilard et al. 2001) identified three chaperone proteins from cow oviducts that bound to bull spermatozoa; two of these were identified as Heat shock $60 \mathrm{kDa}$ protein 1 (chaperonin; HSPD1 previously known as HSP60) and HSPA5 (Boilard et al. 2004). Interestingly, HSPA5 is also present in our sperm-binding $70 \mathrm{kDa}$ sAPM band. Subsequent studies of these proteins have also confirmed their presence in the human female reproductive tract (Lachance et al. 2005). These proteins were found to elevate intracellular calcium concentrations in spermatozoa; (Lachance et al. 2007), thus confirming that the heat shock proteins are able to act upon spermatozoa via plasma membrane mediated cellsignalling mechanisms. This provides supportive evidence that HSPA8 may act via a similar route. In their study, Lachance et al. (2007) were unable to detect any viability enhancing effects of HSPD1 and HSPA5 on human spermatozoa, although given that their duration of incubation was only $4 \mathrm{~h}$, any effects may have been difficult to detect.

Heat shock proteins of similar size and function to those identified here as components of the oviductal epithelium have also been identified as components of spermatozoa themselves. They are known to be synthesized during spermatogenesis (Allen et al. 1988, Maekawa et al. 1989) and they adopt specific localizations within sperm e.g. within their plasma membrane (Boilard et al. 2004, Mitchell et al. 2007). While endogenous heat shock proteins clearly have roles in sperm function, data in the present study clearly show that exogenous heat shock proteins, such as HSPA8 can also have an important effect on sperm function.

Our data showing an important role for HSPA8 in the maintenance of boar and bull sperm survival in vitro implies that the mechanism of action could be highly conserved across species. Consequently, the protein could be a useful additive to sperm extenders used for artificial insemination for more than one species. Indeed, inter-species variability in effectiveness is a major difficulty for the development of sperm extenders in mammals, but we speculate that such a highly conserved protein as HSPA8 may be useful in overcoming this problem.

\section{Materials and Methods}

\section{Materials and reagents}

Reproductive organs from sows were obtained from local abattoirs within 20 min of slaughter, immediately chilled in ice-cold PBS (PBS) and transported to the laboratory. boar semen in beltsville thawing solution (BTS; Pursel \& Johnson 1975) was supplied by JSR Genetics (Thorpe Willoughby, Yorkshire, UK). All reagents, except where stated, were obtained from Sigma-Aldrich; PBS pH 7.2 without calcium and magnesium (Invitrogen); electrophoresis equipment and reagents (Bio-Rad); western blotting reagents including SulfoNHS-LC-biotin (Pierce, Rockford, IL, USA); live-dead stains SYBR-14, PI and ethidium homodimer (ETHD-1; Molecular Probes, Eugene, OR, USA); methanol and glacial acetic acid (BDH, Poole Dorset); antibodies (Abcam plc, Cambridge, UK and Stressgen, Ann Arbor, MI, USA). Bovine recombinant HSPA8 was obtained from Stressgen (Cat no. SPP-751). Two modifications of Tyrode's medium (TLP and TALP) were used in this study; TLP consisted of $2 \mathrm{mM} \mathrm{CaCl}_{2}, 3.1 \mathrm{mM} \mathrm{KCl}, 0.4 \mathrm{mM}$ 
$\mathrm{MgCl}_{2} 6 \mathrm{H}_{2} \mathrm{O}, 100 \mathrm{mM} \mathrm{NaCl}, 25 \mathrm{mM} \mathrm{NaHCO}_{3}, 0.3 \mathrm{mM} \mathrm{NaH}_{2}$ $\mathrm{PO}_{4} 2 \mathrm{H}_{2} \mathrm{O}, 10 \mathrm{mM}$ HEPES, $21.6 \mathrm{mM}$ sodium lactate and $1 \mathrm{mM}$ sodium pyruvate. Sometimes the TLP was supplemented with $12 \mathrm{mg} / \mathrm{ml}$ BSA and we therefore refer to it as TALP (TLP+Albumin).

\section{Apical plasma membrane preparations}

\section{Unlabelled fractions}

The OEC from the reproductive tissue of freshly slaughtered sows were harvested manually and the sAPM fractions were isolated and solubilized as described previously (Holt et al. 2005). Briefly, epithelial cells were scraped from the lumena of oviducts and sequentially and alternately treated with $10 \mathrm{mM}$ $\mathrm{MgCl}_{-2}$ and differential centrifugation to release the APMs. Soluble proteins were extracted from the membranes with $1 \mathrm{M}$ $\mathrm{NaCl}$ and high-speed centrifugation. The supernatant was separated from the pellet and concentrated using Microcon 3000 Dalton cut-off centrifugal filter devices (Millipore UK Ltd, Watford, UK). The concentrated sAPM protein fraction was washed twice with TLP and stored at $? 80^{\circ} \mathrm{C}$. Protein concentration was measured using the Bradford (1976) method (kit supplied by Bio-Rad).

\section{Biotin labelled sAPM fractions}

Prior to epithelial cell collection and SAPM preparation the oviductal lumena were labelled with biotin ester Sulpho-NHSLC-biotin (Pierce). This involved filling the oviducts with the prepared biotin ester $(0.5 \mathrm{mg} / \mathrm{ml})$ and incubating them for $30 \mathrm{~min}$. The excess biotin was quenched by flushing with $50 \mathrm{mM} \mathrm{NH}_{4} \mathrm{Cl}$. sAPM proteins were prepared using the same method as that for the unlabelled fractions.

\section{Sperm preparation}

Viable boar sperm samples were separated from the storage diluent, usually BTS, by washing through a Percoll-saline concentration gradient (Holt \& Harrison 2002). Semen aliquots (7 ml) were layered over $2 \mathrm{ml} \mathrm{35 \%}$ Percoll on $2 \mathrm{ml} \mathrm{70 \%} \mathrm{Percoll}$ and centrifuged for $15 \mathrm{~min}$ at $200 \mathrm{~g}$ followed by $15 \mathrm{~min}$ at $900 \mathrm{~g}$. The supernatant was aspirated to leave $\sim 0.4 \mathrm{ml}$ containing the sperm pellet.

Bull semen was supplied by Genus Freezing Unit, (Ruthin, Wales), in 1:5 dilution of Eqcellsire (IMV L'Aigle, France) and cooled to room temperature prior to overnight dispatch to our laboratory. A total of eight ejaculates were used in the current study. The samples were centrifuged for $10 \mathrm{~min}$ at $600 \mathrm{~g}$ and the supernatant removed. The sperm pellet was washed once and then diluted in TALP to give a sperm concentration of $100 \times 10^{6} / \mathrm{ml}$ (final concentration $50 \times 10^{6} \mathrm{sperm} / \mathrm{ml}$ ).

\section{Evaluation of sperm viability}

Sperm viability (as defined by plasma membrane integrity) was assessed using SYBR-14 (200 nM) and ETHD-1 (2 $\mu \mathrm{M})$ in PBS supplemented with $0.01 \%(\mathrm{v} / \mathrm{v})$ formalin. Spermatozoa were incubated in this solution for $15 \mathrm{~min}$ at $39{ }^{\circ} \mathrm{C}$ in $5 \% \mathrm{CO}_{2}$ and at least 200 cells were counted and classified as live (plasma membrane-intact; green) or dead (plasma membrane damaged; red). The data were expressed as mean viability index \pm s.E.M. Viability index was defined as the ratio of \% viable spermatozoa at time $=24 \mathrm{~h} / \%$ viable spermatozoa at time $=0 \mathrm{~h}$.

\section{Evaluation of interactions between in situ biotinylated sAPM and spermatozoa}

Samples of in situ biotinylated sAPM were adjusted to $3 \mathrm{mg} / \mathrm{ml}$ in $200 \mu \mathrm{l}$ Immobilized Neutravidin coated agarose beads in PBS (Pierce). The samples were incubated for $1 \mathrm{~h}$ on a small shaker at $600 \mathrm{rpm}$ (room temperature). The bead/sAPM samples were centrifuged to remove unbound protein and washed in $5 \times 1 \mathrm{ml}$ PBS for $2 \mathrm{~min}$ each at $2500 \mathrm{~g}$. A sample of beads without added sAPM was also washed. The final pellet of beads was resuspended in $100 \mu$ I TLP. Boar semen was washed in a Percoll-saline concentration gradient as described above; $2 \mu \mathrm{l}$ aliquants of washed spermatozoa were added to each of three tubes containing $25 \mu \mathrm{l}$ each of 1) TLP only, 2) beads without SAPM and 3) beads with SAPM; these were incubated for $20 \mathrm{~min}$ at $39{ }^{\circ} \mathrm{C}$ in $5 \% \mathrm{CO}_{2}$. Clean electropositive slides (VWR, Lutterworth, UK) were prepared by warming to $37^{\circ} \mathrm{C}$. After $20 \mathrm{~min}$ an aliquot $(10 \mu \mathrm{l})$ of the incubated sample was mounted on a slide beneath a coverslip. The coverslips were raised $>65 \mu \mathrm{m}$ above the slide surface using small amounts of silicon grease mixed with $65 \mu \mathrm{m}$ diameter glass beads. The sperm-bead interactions were recorded on video tape for observation; two observers made blind and independent estimates of the number of spermatozoa bound to beads.

\section{Microscopic localization of sAPM proteins on the surface of spermatozoa}

sAPM proteins were labelled with FITC using a ProtOn Fluorescein labelling kit (Vector Laboratories Inc., Burlingame, CA, USA) following the manufacturer's instructions. Briefly, $100 \mu \mathrm{l}$ sAPM $(7.0 \mathrm{mg} / \mathrm{ml})$ was supplemented with $2 \mu \mathrm{l}$ ProtOn FITC reagent and incubated for $30 \mathrm{~min}$ at room temperature. The reaction was stopped with $2 \mu$ l ethanolamine $(1 \mathrm{M})$ and incubated for $5 \mathrm{~min}$ at room temperature. The sample was passed through the salt extraction column provided (by centrifugation at $500 \mathrm{~g}$ for $1 \mathrm{~min}$ ) to remove excess fluorescein. The protein concentration of the sample was then assessed (Bradford 1976).

The labelled protein $(2.4 \mathrm{mg} / \mathrm{ml})$ was diluted in TLP $(1: 10$ v/v). $2 \mu \mathrm{l}$ Percoll-saline washed spermatozoa was added to $100 \mu \mathrm{l}$ aliquots of this labelled protein solution. The samples were incubated at $39{ }^{\circ} \mathrm{C}$ for $10 \mathrm{~min}$ prior to the addition of $1 \mu \mathrm{l}$ $\mathrm{PI}$ for a further $3 \mathrm{~min}$. These samples were centrifuged for $3 \mathrm{~min}$ at $3000 \mathrm{~g}$ : the supernatant was removed and the samples resuspended in $80 \mu \mathrm{l} \mathrm{TLP}$. Aliquots were examined by confocal microscopy (Zeiss LSM 510, Oberkochen Germany). At least ten images of spermatozoa from each boar were recorded. Sperm/sAPM localization was assessed subjectively as to whether there was 'no binding', 'binding to the acrosomal region' or 'binding to the head and mid-piece region'. Approximately 60 plasma membrane intact spermatozoa were evaluated from each of eight boar ejaculates. 


\section{In vitro fertilization technique}

Sow ovaries were obtained from a local abattoir (A \& G Barber, Purleigh, Essex, UK); these were placed in $0.9 \%$ saline solution supplemented with $100 \mathrm{IU} / \mathrm{ml}$ penicillin-G and $100 \mu \mathrm{g} / \mathrm{ml}$ streptomycin sulphate solution (pen/strep; Invitrogen Life Technologies) and maintained in a thermos flask at $25-30{ }^{\circ} \mathrm{C}$ for transportation to the laboratory. On arrival the ovaries were washed in lukewarm water then rinsed in warm saline solution with pen/strep supplements.

Follicular fluid from 3-6 mm diameter ovarian follicles were aspirated using an 18.5 gauge needle attached to a $10 \mathrm{ml}$ disposable syringe containing $2 \mathrm{ml}$ collection medium 1 (TCM 199 supplemented with $5 \mathrm{mM} \mathrm{NaHCO}, 15 \mathrm{mM}$ Hepes $\left(\mathrm{Na}^{+}\right.$salt or free acid), $0.05 \mathrm{~g} / \mathrm{l}$ kanamycin sulphate, $0.4 \%(\mathrm{w} / \mathrm{v})$ BSA fraction $\mathrm{V}$ and $0.04 \mathrm{~g} / \mathrm{l}$ heparin). The aspirated fluid was then filtered through a $70 \mu \mathrm{m}$ cell strainer to harvest the oocytes. The oocytes were washed and collected into pre-warmed collection medium 2 (TCM 199 (with Hank's salts and sodium bicarbonate) supplemented with $0.1 \%(\mathrm{w} / \mathrm{v})$ polyvinyl alcohol, $3.05 \mathrm{mM}$ D-glucose, $0.91 \mathrm{mM}$ sodium pyruvate and pen-strep solution). Cumulus-oocyte complexes (COCs) were collected under a stereomicroscope; oocytes had at least two complete layers of cumulus cells and evenly granulated ooplasm. The selected COCs were washed in collection medium 2 and transferred in groups of 50 COCs into pre-equilibrated $500 \mathrm{ml}$ wells of IVM medium (TCM 199 (with Earle's salts, L-glutamine and sodium bicarbonate) and supplemented with $0.1 \%$ polyvinyl alcohol, $3.05 \mathrm{mM}$ D-glucose, $0.91 \mathrm{mM}$ sodium pyruvate, $0.57 \mu \mathrm{M}$ cysteine and $10 \mathrm{ng} / \mathrm{ml}$ epidermal growth factor and pen-strep solution (Abeydeera et al. 2000) and pre-equilibrated). Before oocyte transfer $0.5 \mu \mathrm{g} / \mathrm{ml} \mathrm{LH}$ and $0.5 \mu \mathrm{g} / \mathrm{ml} \mathrm{FSH}$ were added to the $500 \mu \mathrm{l}$ maturation droplets. The preparations were incubated for $48 \mathrm{~h}$.

After IVM incubation $0.1 \%(\mathrm{w} / \mathrm{v})$ hyaluronidase was added for $30 \mathrm{~min}$ to the maturation droplets to loosen the cumulus cells. COCs were then washed in pre-equilibrated mTBM (modified Tris-buffered medium (mTBM (Abeydeera \& Day 1997): $113.1 \mathrm{mM} \mathrm{NaCl}, 3 \mathrm{mM} \mathrm{KCl}, 20 \mathrm{mM}$ Tris-base, $11 \mathrm{mM}$ D-glucose and $5 \mathrm{mM}$ sodium pyruvate supplemented with $5 \mathrm{mM} \mathrm{NaHCO}_{3}$ and $\left.0.4 \%(\mathrm{w} / \mathrm{v}) \mathrm{BSA}\right)$. After equilibration of the medium, $10 \mathrm{mM} \mathrm{CaCl}_{2}$ was added to avoid precipitation). Groups of 30-40 COCs were placed in pre-equilibrated $98 \mu \mathrm{l}$ droplets of mTBM covered in mineral oil. Approximately $3 \times 10^{6} \mathrm{ml}$ of Percoll-washed spermatozoa were incubated for $10 \mathrm{~min}$ in $1 \mathrm{ml}$ pre-equilibrated mTBM supplemented with, or left without, $0.5 \mu \mathrm{g} / \mathrm{ml}$ bovine recombinant HSPA8. $2 \mu \mathrm{l}$ sperm suspension were added to the IVF droplets, to give a final concentration of $6 \times 10^{4}$ spermatozoa $/ \mathrm{ml}$. The oocytes and spermatozoa were co-incubated for $6 \mathrm{~h}$.

Following sperm-oocyte co-incubation, the presumptive zygotes were collected into $1 \mathrm{ml}$ pre-equilibrated NCSU23 medium (North Carolina State University-23 medium: $108.73 \mathrm{mM} \mathrm{NaCl}, 4.78 \mathrm{mM} \mathrm{KCl}, 1.19 \mathrm{mM} \mathrm{K}_{2} \mathrm{PO}_{4}, 1.19 \mathrm{mM}$ $\mathrm{MgSO}_{4} .7 \mathrm{H}_{2} \mathrm{O}, 1 \mathrm{mM}$ L-glutamine, $5.55 \mathrm{mM}$ D-glucose, $7 \mathrm{mM}$

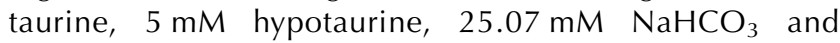
$1.71 \mathrm{mM} \mathrm{CaCl}_{2}$ supplemented with $0.4 \%$ (w/v) BSA and pen-strep solution) in a $5 \mathrm{ml}$ glass tube and vortexed for
2 min to remove loosely bound spermatozoa and cumulus cells. The presumptive zygotes were then washed twice in fresh pre-equilibrated $40 \mu \mathrm{l}$ droplets of NCSU23 and transferred to $20 \mu \mathrm{l}$ of the same medium in groups of 20-25. They were cultured for $48 \mathrm{~h}$ and then fixed in $2.5 \%$ paraformaldehyde fixative with $0.5 \%$ triton $\mathrm{X}-100$ for $30 \mathrm{~min}$ at $39{ }^{\circ} \mathrm{C}$. The embryos were washed $(\times 3)$ in warm PBS and stained with $10 \mu \mathrm{g} / \mathrm{ml} \mathrm{PI}$ for $10 \mathrm{~min}$ before being mounted in mounting medium (Vectashield, Vector Laboratories). They were examined by confocal microscopy (Zeiss LSM 510, Germany) to identify fertilization status. The oocytes/embryos were classified as 1) unfertilized oocytes (the presence of metaphase plates or female pronuclei), 2) fertilized, with male and female pronuclei, 3) one-cell embryos, 4) cleaved embryos with two or more cells 5) embryos with more than four cells.

\section{Identification of the oviductal epithelial proteins that bound to spermatozoa}

Biotinylated APM and SAPM (prepared ex situ and in situ) was incubated with spermatozoa $\left(150 \mu \mathrm{g} / \mathrm{ml}\right.$ and $1 \times 10^{8}$ spermatozoa $/ \mathrm{ml}$ ) at $39{ }^{\circ} \mathrm{C}$ and $5 \% \mathrm{CO}_{2}$ in air for $30 \mathrm{~min}$. After incubation the sperm suspensions were concentrated by microcentrifugation and then washed three or four times ( $>$ 1:100 dilution per wash) by microcentrifugation at $5000 \mathrm{~g}$ for $4 \mathrm{~min}$ for removal of APM and SAPM. To prepare a suspension of biotinylated proteins bound to sperm membranes, the washed pellets were resuspended in SDS sample buffer $(50 \mathrm{mmol}$ tris/l pH 6.8 and $0.5 \%$ SDS w/v), incubated at room temperature for $90 \mathrm{~min}$ and then centrifuged at $14000 \mathrm{~g}$ for $10 \mathrm{~min}$. The supernatant (soluble fraction, comprising sperm membrane proteins and surfacebound biotinylated proteins) was aspirated for evaluation by one-dimensional PAGE and immunoblotting to detect biotinylated proteins.

A biotin-positive band in the immunoblot of sperm proteins corresponded to a $70 \mathrm{kDa}$ band in the PAGE gel preparation. This band was therefore excised and analyzed further. To prepare sufficient protein for proteomic analysis SAPM proteins were separated using 16 single-dimensional PAGE lanes and the appropriate band in each was extracted for analysis. Specifically, this was achieved as follows. Protein $(15 \mu \mathrm{g})$ was loaded into each of eight wells in two 10-well gels. The two outer wells of each gel were loaded with Kaleidoscope standards for identification of molecular weight. Electrophoresis was performed, using the discontinuous buffer system (Laemmli 1970) for $45 \mathrm{~min}$ at 190 volts after which the gels were fixed (40\% methanol $\mathrm{v} / \mathrm{v}$ and $7 \%$ glacial acetic acid) for $1 \mathrm{~h}$ and stained overnight in Brilliant Blue G-Colloidal Concentrate. The gels were destained in $10 \%$ acetic acid in $25 \%$ methanol $(\mathrm{v} / \mathrm{v})$ for $30 \mathrm{~s}$ and rinsed in $25 \%$ methanol before being placed carefully onto clean glass plates. Using a new sterile blade, the prominent band (Fig. 2A arrow) corresponding to the $70 \mathrm{kDa}$ in situ sAPM biotinylated protein that bound to spermatozoa (Fig. 2B arrows) was excised from each of the 16 separate sAPM lanes. Each piece was cut into $1 \mathrm{~mm}^{2}$ pieces and placed in $1 \mathrm{ml} \mathrm{dH_{- }}$ O in $1.8 \mathrm{ml}$ centrifuge tubes for further proteomic processing. 


\section{Proteomic analysis}

Gel pieces were washed in $25 \%(\mathrm{v} / \mathrm{v})$ methanol, and then incubated for $1 \mathrm{~h}$ at $37^{\circ} \mathrm{C}$ in Coomassie destain solution consisting of $40 \%(\mathrm{v} / \mathrm{v})$ acetonitrile (ACN: VWR International Ltd., Leicester, UK) in $200 \mathrm{mM}$ ammonium bicarbonate. The destain solution was removed, and gel pieces were incubated with $\mathrm{ACN}$ for $15 \mathrm{~min}$ at room temperature. $\mathrm{ACN}$ was subsequently removed, and the gel pieces were dried in a vacuum centrifuge. Dried gel pieces were stored at $4{ }^{\circ} \mathrm{C}$ until required. Proteins were digested with $20 \mathrm{ng} / \mu \mathrm{l}$ sequencing grade modified trypsin (Promega) in $50 \mathrm{mM}$ ammonium bicarbonate at $37^{\circ} \mathrm{C}$ for $12 \mathrm{~h}$. The supernatant from the trypsin digest was transferred to a siliconized microcentrifuge tube. Peptides were sequentially extracted three times by incubation with peptide extraction solution consisting of $25 \mathrm{mM}$ ammonium bicarbonate $(10 \mathrm{~min}$ at room temperature), 5\% formic acid $\left(15 \mathrm{~min}\right.$ at $\left.37^{\circ} \mathrm{C}\right)$, and $\mathrm{ACN}(15 \mathrm{~min}$ at $\left.37^{\circ} \mathrm{C}\right)$. Each extraction was followed by centrifugation and removal of supernatants. The original supernatant and the supernatants from the three sequential extractions were combined and dried in a vacuum centrifuge for $4-6 \mathrm{~h}$. The dried peptides were dissolved in $7 \mu \mathrm{l} 0.1 \%(\mathrm{v} / \mathrm{v})$ formic acid in $3 \%(\mathrm{v} / \mathrm{v}) \mathrm{ACN}$ in water. Samples were centrifuged for $5 \mathrm{~min}$ at $12000 \mathrm{~g}$, and the supernatants were subjected to liquid chromatography electrospray ionization tandem mass spectrometry (LC-ESI-MS/MS).

Liquid chromatographic separations of the tryptic digests were performed using a reverse phase CapLC system (Waters, Manchester, UK). Peptides were desalted by a PepMap $C_{18}$ microguard column $(300 \mu \mathrm{m}$ internal diameter $\times 1 \mathrm{~mm}$; LC-Dionex, Leeds, UK) and were then transferred to the analytical column (PepMap $\mathrm{C}_{18} ; 75 \mu \mathrm{m}$ internal diameter $\times$ $15-\mathrm{cm}$ column (LC-Dionex). The peptides were eluted in a 60 min gradient. The compositions of the hydrophilic and hydrophobic solvents were $5 \% \mathrm{ACN}, 0.1 \%$ formic acid and $95 \% \mathrm{ACN}, 0.1 \%$ formic acid. The column eluent was sprayed directly into the nano-ESI source of a Q-TOF microcolumn (Waters). An initial MS scan was performed, and selection of ions for CID was automated by Mass Lynx software (Waters). CID selection criteria were set for $2+$ and $3+$ ions within the range of $400-2000 \mathrm{~m} / \mathrm{z}$ above 10 ion counts.

Spectra were searched against the mass spectrometry data base in a sequence query search using MASCOT 2.2.03 software (www.matrixscience.com). The taxonomy was limited to filter for only mammalian matches, and trypsin was used as the cleavage enzyme with one missed cleavage site allowed. The peptide tolerance was set to $1.2 \mathrm{kDa}$, and the MS/MS tolerance was set to $0.6 \mathrm{kDa}$. Carbamidomethyl modifications of cysteine and oxidized methionine were set as variable modifications. Matches were considered valid if MS/MS data for multiple unique peptides per protein were identified, each with ion scores above the threshold of statistical significance (values generated by MASCOT). Manual examination of MS/ MS data was performed for single peptide matches. In these cases, a continuous stretch of peptide sequence covered by either the $y$ - or b-ion series was required for the protein match to be considered valid.

\section{Western blot analysis of SAPM}

The proteomic analysis indicated that spermatozoa avidly bound a series of heat shock proteins. Of these, we chose to examine HSPA8 in more detail. First, for independent confirmation that HSPA8 was indeed present in SAPM a western blot were performed. sAPM proteins were separated by SDS-PAGE (10\% gel), blotted on to nitrocellulose and incubated in blocking buffer for $1 \mathrm{~h}$. Anti-HSPA8 (SPA-815), at the manufacturer's recommended dilution was added to the blot and incubated for $1 \mathrm{~h}$ at room temperature. The blot was washed $6 \times 10$ min in tris-buffered saline (Pierce) supplemented with tween-20 (TTBS) followed by the addition of the goat antirat secondary antibody conjugated with alkaline phosphatase (AP; ab7098, Abcam), at the manufacturer's recommended dilution for a further hour. The blot was washed $6 \times 10 \mathrm{~min}$ in TTBS and, finally, incubated for $3 \mathrm{~min}$ in Lumi-phos for AP (Pierce) detection. The blot was exposed to X-ray film for periods between 5 and $60 \mathrm{~s}$.

\section{Sperm viability assays}

Boar sperm viability in the presence of antibody-treated SAPM

Antibody-treated sAPM $(200 \mu \mathrm{g} / \mathrm{ml})$ was prepared by incubating sAPM with $1 \mu \mathrm{g} / \mathrm{ml}$ anti-HSPA8 (Ab1427) in TLP for $2 \mathrm{~h}$ on a rotary shaker at room temperature. Then, semen from eight boars was individually washed with Percoll-saline as previously described and each sample (in TALP) was adjusted to give a final concentration of $25 \times 10^{6}$ spermatozoa $/ \mathrm{ml} .15 \mu \mathrm{l}$ droplets of sperm suspension and antibody-treated sAPM (with untreated SAPM and TLP as control treatments) were mixed 1:1 in $20 \mathrm{~mm}$ diameter wells in four well Multi-dish plates (Sigma Aldrich) and then covered with mineral oil. They were incubated at $39{ }^{\circ} \mathrm{C}$ in $5 \% \mathrm{CO}_{2}$ for $24 \mathrm{~h}$. The viability of spermatozoa was assessed at zero hours and after $24 \mathrm{~h}$.

Dose response effect of HSPA8 protein on boar sperm viability

Boar spermatozoa were prepared for the bioassay as previously described. Semen samples from seven boars were used for series 1 and eight boars for series 2. Recombinant bovine HSPA8 (Stressgen; SPP-751) was diluted in TLP to give final concentrations of $16,8,4$ and $2 \mu \mathrm{g} / \mathrm{ml}$ (series 1) and 8, 2, 0.5 and $0.25 \mu \mathrm{g} / \mathrm{ml}$ (series 2) when incubated with equal volumes of spermatozoa. Control samples were incubated in TLP only or TLP $+\operatorname{sAPM}(200 \mu \mathrm{g} / \mathrm{ml})$. The samples were incubated at $39{ }^{\circ} \mathrm{C}$ in $5 \%$ $\mathrm{CO}_{2}$ for $24 \mathrm{~h}$. Sperm viability was examined as described earlier.

\section{Effect of HSPA8 protein on bull sperm viability}

Serial dilutions of bovine recombinant HSPA8 and a control protein $\alpha$ tubulin were prepared in TALP to give final concentrations of 4, 1, 0.5 and $0.1 \mu \mathrm{g} / \mathrm{ml}$. Spermatozoa were added to droplets of TALP, TALP $+\alpha$ tubulin (Abcam plc) or TALP + recombinant HSPA8 in equal volumes of $25 \mu \mathrm{l}$ each. The $50 \mu \mathrm{l}$ droplets were covered with mineral oil and incubated at $37^{\circ} \mathrm{C}$ in a $5 \% \mathrm{CO}_{2}$ incubator for $48 \mathrm{~h}$. The viability of samples was assessed at zero hours and then at $48 \mathrm{~h}$ following the same procedure as that for boar spermatozoa. 


\section{Statistical analyses}

Percentage and Viability Index data were log transformed and treatment effects were examined using analyses of variance (Statistica for Windows V7; Statsoft UK, Letchworth, UK). Individual contrasts between treatments were examined using orthogonal polynomial coefficients. Treatment effects in the IVF experiment were analyzed using Fisher's exact $\chi^{2}$-tests. Sperm - bead binding effects were assessed using the non-parametric Mann-Whitney $U$ test.

\section{Declaration of interest}

The authors declare that there is no conflict of interest that could be perceived as prejudicing the impartiality of the research reported.

\section{Funding}

This study was funded by grants from the Biotechnology and Biological Sciences Research Council and the London Development Agency's Heptagon Fund.

\section{Acknowledgements}

We are grateful to Dr Elena Badia for her assistance with elucidating the proteomics data and to Dr Abdul Al-Haider for assistance with the IVF experiments. We also thank JSR Genetics (Thorpe Willoughby, UK) for supplying the boar semen used in these experiments.

\section{References}

Abeydeera LR \& Day BN 1997 Fertilization and subsequent development in vitro of pig oocytes inseminated in a modified tris-buffered medium with frozen-thawed ejaculated spermatozoa. Biology of Reproduction $\mathbf{5 7}$ 729-734.

Abeydeera LR, Wang WH, Cantley TC, Rieke A, Murphy CN, Prather RS \& Day BN 2000 Development and viability of pig oocytes matured in a protein-free medium containing epidermal growth factor. Theriogenology 54 787-797.

Allen RL, O'Brien DA, Jones CC, Rockett DL \& Eddy EM 1988 Expression of heat shock proteins by isolated mouse spermatogenic cells. Molecular and Cellular Biology 8 3260-3266.

Boilard M, Reyes-Moreno C \& Sirard MA 2001 Binding of chaperonins to bovine spermatozoa by direct contact to apical plasma membrane of oviduct epithelial cells. Biology of Reproduction 64112.

Boilard M, Reyes-Moreno C, Lachance C, Massicotte L, Bailey JL, Sirard MA \& Leclerc P 2004 Localization of the chaperone proteins GRP78 and HSP60 on the luminal surface of bovine oviduct epithelial cells and their association with spermatozoa. Biology of Reproduction 71 1879-1889.

Boulanger J, Faulds D, Eddy EM \& Lingwood CA 1995 Members of the $70 \mathrm{kDa}$ heat shock protein family specifically recognize sulfoglycolipids: role in gamete recognition and mycoplasma-related infertility. Journal of Cellular Physiology 165 7-17.

Bradford MM 1976 A rapid and sensitive method for the quantitation of microgram quantities of protein utilizing the principle of protein-dye binding. Analytical Biochemistry 72 248-254.

Daugaard M, Rohde M \& Jaattela M 2007 The heat shock protein 70 family: highly homologous proteins with overlapping and distinct functions. FEBS Letters 581 3702-3710.

Elliott RMA, Duncan A, Watson PF, Holt WV \& Fazeli AR 2001 Peripheral bound membrane proteins are involved in the maintenance of boar sperm viability by oviductal apical plasma membrane preparations in vitro. Molecular Biology of the Cell 12 117a.
Fazeli A, Duncan AE, Watson PF \& Holt WV 1999 Sperm-oviduct interaction: induction of capacitation and preferential binding of uncapacitated spermatozoa to oviductal epithelial cells in porcine species. Biology of Reproduction 60 879-886.

Fazeli A, Elliott RM, Duncan AE, Moore A, Watson PF \& Holt WV 2003 In vitro maintenance of boar sperm viability by a soluble fraction obtained from oviductal apical plasma membrane preparations. Reproduction 125 509-517.

Gadella BM, Lopes-Cardozo M, Vangolde LMG, Colenbrander B \& Gadella TWJ 1995 Glycolipid migration from the apical to the equatorial subdomains of the sperm head plasma-membrane precedes the acrosome reaction - evidence for a primary capacitation event in boar spermatozoa. Journal of Cell Science 108 935-946.

Galbraith DA 1993 Multiple paternity and sperm storage in turtles. Herpetological Journal 3 117-123.

Georgiou AS, Sostaric E, Wong CH, Snijders AP, Wright PC, Moore HD \& Fazeli A 2005 Gametes alter the oviductal secretory proteome. Molecular and Cellular Proteomics 4 1785-1796.

Gist DH \& Congdon JD 1998 Oviductal sperm storage as a reproductive tactic of turtles. Journal of Experimental Zoology 282 526-534.

Holt WV \& Harrison RA 2002 Bicarbonate stimulation of boar sperm motility via a protein kinase A-dependent pathway: between-cell and between-ejaculate differences are not due to deficiencies in protein kinase A activation. Journal of Andrology 23 557-565.

Holt WV, Elliott RMA, Fazeli A, Satake N \& Watson PF 2005 Validation of an experimental strategy for studying surface-exposed proteins involved in porcine sperm-oviduct contact interactions. Reproduction, Fertility, and Development 17 683-692.

Holt WV, Elliott RM, Fazeli A, Sostaric E, Georgiou AS, Satake N, Prathalingam N \& Watson PF 2006 Harnessing the biology of the oviduct for the benefit of artificial insemination. Society of Reproduction and Fertility 62 247-259.

Hunter RHF 1981 Sperm transport and reservoirs in the pig oviduct in relation to the time of ovulation. Journal of Reproduction and Fertility $\mathbf{6 3}$ 109-117.

Hunter RH \& Rodriguez-Martinez H 2004 Capacitation of mammalian spermatozoa in vivo, with a specific focus on events in the Fallopian tubes. Molecular Reproduction and Development 67 243-250.

Lachance C, Boilard M \& Leclerc P 2005 Effect of HSP60 and GRP78 on human sperm functions. Journal of Andrology (Supplement) S39.

Lachance C, Bailey JL \& Leclerc P 2007 Expression of Hsp60 and Grp78 in the human endometrium and oviduct, and their effect on sperm functions. Human Reproduction 22 2606-2614.

Laemmli UK 1970 Cleavage of structural proteins during the assembly of the head of bacteriophage T4. Nature 227 680-685.

Lingwood CA, Mylvaganam M, Whetstone H, Mamelak D \& Kiso M 2001 Specific binding and modulation of hsp70 by sulfogalactolipids. FASEB Journal 15 A866.

Maekawa M, O'Brien DA, Allen RL \& Eddy EM 1989 Heat-shock cognate protein (hsc71) and related proteins in mouse spermatogenic cells. Biology of Reproduction 40 843-852.

Mamelak D, Mylvaganam M, Tanahashi E, Ito H, Ishida H, Kiso M \& Lingwood C 2001 The aglycone of sulfogalactolipids can alter the sulfate ester substitution position required for hsc70 recognition. Carbohydrate Research 335 91-100.

Mitchell LA, Nixon B \& Aitken RJ 2007 Analysis of chaperone proteins associated with human spermatozoa during capacitation. Molecular Human Reproduction 13 605-613.

Pacey AA, Hill CJ, Scudamore IW, Warren MA, Barratt CLR \& Cooke ID 1995 The interaction in vitro of human spermatozoa with epithelial cells from the human uterine (Fallopian) tube. Human Reproduction 10 360-366.

Pollard JW, Plante C, King WA, Hansen PJ, Betteridge KJ \& Suarez SS 1991 Fertilizing-capacity of bovine sperm may be maintained by binding to oviductal epithelial-cells. Biology of Reproduction $\mathbf{4 4}$ 102-107.

Pratt HL \& Tanaka S 1994 Sperm storage in male elasmobranchs; a description and a survey. Journal of Morphology 219 297-308.

Pursel VG \& Johnson LA 1975 Freezing of boar spermatozoa: fertilizing capacity with concentrated semen and a new thawing procedure. Journal of Animal Science 40 99-102. 
Racey PA 1979 The prolonged storage and survival of spermatozoa in Chiroptera. Journal of Reproduction and Fertility 56 391-402.

Racey PA \& Potts DM 1970 Relationship between stored spermatozoa and the uterine epithelium in the pipistrelle bat (Pipistrellus pipistrellus). Journal of Reproduction and Fertility 22 57-63.

Racey PA, Uchida TA, Mori T, Avery MI \& Fenton MB 1987 Spermepithelium relationships in relation to the time of insemination in little brown bats (Myotis lucifugus). Journal of Reproduction and Fertility $\mathbf{8 0}$ 445-454.

Rodriguez-Martinez H 2007 Role of the oviduct in sperm capacitation. Theriogenology 68 S138-S146.

Rodriguez-Martinez H, Saravia F, Wallgren M, Tienthai P, Johannisson A, Vazquez JM, Martinez E, Roca J, Sanz L \& Calvete JJ 2005 Boar spermatozoa in the oviduct. Theriogenology 63 514-635.

Satake N, Elliott RM, Watson PF \& Holt WV 2006 Sperm selection and competition in pigs may be mediated by the differential motility activation and suppression of sperm subpopulations within the oviduct. Journal of Experimental Biology 209 1560-1572.
Satake N, Alhaider AK, Holt WV \& Watson PF 2007 Exposure of spermatozoa to solubilized extracts of the oviductal epithelium apical plasma membrane enhances fertilization in porcine in vitro fertilization. Reproduction, Fertility, and Development 19272.

Sever DM \& Brizzi R 1998 Comparative biology of sperm storage in female salamanders. Journal of Experimental Zoology 282 460-476.

Smith TT \& Nothnick WB 1997 Role of direct contact between spermatozoa and oviductal epithelial cells in maintaining rabbit sperm viability. Biology of Reproduction 56 83-89.

Tavaria M, Gabriele T, Kola I \& Anderson RL 1996 A hitchhiker's guide to the human Hsp70 family. Cell Stress and Chaperones 1 23-28.

Received 9 July 2008

First decision 20 August 2008

Revised manuscript received 27 September 2008

Accepted 7 November 2008 